\title{
SINERGITAS KELOMPOK TANI, PRODUSEN, PASAR DAN PEMERINTAH DAERAH TERHADAP KESINAMBUNGAN PENGOLAHAN KOPI KEMASAN SEBAGAI PRODUK UNGGULAN DAERAH
}

\author{
Folkes E. Laumal ${ }^{1}$, Jhon A. Wabang ${ }^{2}$, Paulus Edi Plaimo ${ }^{3}$, Raden S. B. Suharto ${ }^{4}$ \\ ${ }_{1,2,4}$ Politeknik Negeri Kupang \\ Jl. Adi Sucipto Penfui Klp. Lima, Kota Kupang, NTT \\ ${ }^{3}$ Universitas Tribuana Kalabahi \\ Jl. Singamangaraja No 24, Kab. Alor, NTT \\ Email Korespondensi: folkeslaumal76@gmail.com
}

\begin{abstract}
ABSTRAK
Produksi kopi kemasan dari Kabupaten Alor yang didampingi melalui program pengabdian masyarakat dari DRPM Ristekdikti memberikan dampak peningkatan produksi pada 2 tahun terakhir. Peningkatan tersebut dipengaruhi oleh pendampingan dan promosi yang terus-menerus dilakukan oleh berbagai pihak termasuk pemerintah daerah Kabupaten Alor. Untuk menjamin keberlanjutan pengelolaannya dan dapat dijual secara nasional, maka sebuah sinergitas telah dilakukan melalui kegiatan lokakarya yang melibatkan 5 Kelompok Tani Kopi dari Desa Manmas Kecamatan Alor Selatan, KUD beringin dan UPH Perkebunan yang memproduksi Kopi Lonsilar dan Kopi Cita Rasa Khas Alor, Pemerintah Daerah yang diwakili oleh Dinas Pertanian Perkebunan Kabupaten Alor dan PT Transmart sebagai salah satu pasar modern yang siap menjadi pembeli produk-produk olahan daerah.
\end{abstract}

Kata Kunci: Kopi Cita Rasa Khas Alor; Kopi Lonsilar; Pengabdian Masyarakat

\begin{abstract}
Production of packaged coffee from Alor Regency, which was accompanied by a community service program from RPM Ristekdikti, has had an impact on increasing production in the last 2 years. The increase was influenced by the ongoing assistance and promotion by various parties including the local government of Alor Regency. To ensure the sustainability of its management and can be sold nationally, a synergy has been carried out through workshops involving 5 Coffee Farmer Groups from Manmas Village, Alor Selatan District, Banyan KUD and UPH Plantation that produce Lonsilar Coffee and Alor Distinctive Coffee, Alor Local Government represented by the Agriculture Service Office of Alor Regency and PT Transmart as one of the modern markets that are ready to become buyers of regional processed products.
\end{abstract}

Keywords: Alor Typical Coffee; Lonsilar Coffee; Community dedication 


\section{PENDAHULUAN}

Kebijakan Presiden melalui Undang-Undang Nomor 32 Tahun 2004 tentang Pemerintahan Daerah, telah memberikan otonomi yang luas kepada setiap pemerintah daerah untuk mengurus dan mengelola berbagai kepentingan dan kesejahteraan masyarakat di daerah. Pemerintah Daerah harus mengoptimalkan berbagai potensi di wilayahnya untuk pembangunan daerah dengan berorientasi pada kepentingan masyarakat luas. Melalui Undang-Undang Nomor 32, pemerintah daerah dan masyarakat menjadi lebih diberdayakan sekaligus diberi tanggung jawab untuk mempercepat laju pembangunan (Indonesia, 2004). Kabupaten Alor di Nusa Tenggara Timur adalah salah satu wilayah yang memiliki posisi strategis dalam pengembangan ekonomi daerah karena berbatasan langsung dengan Negara Timor Leste (Ma'rif, 2016; Rema \& Prihatmoko, 2016). Kabupaten ini memiliki berbagai sumber daya alam potensial yang belum diolah secara optimal untuk peningkatan ekonomi masyarakat, termasuk peluang peningkatan pendapatan daerah dan ekspor. Salah satu sumber daya alam yang memiliki peluang pengembangan pengelolaan dan memberi efek terhadap perekonomian masyarakat dan daerah adalah sektor perkebunan dan pengolahan hasil-hasilnya (Kelapa, Vanili, Kemiri, Jambu Mente dan Kopi) (Gorangmau, 2016). Meskipun demikian berbagai upaya pengelolaan hasil perkebunan telah dimulai oleh UMKM, koperasi dan kelompok petani yang tersebar di wilayah Kabupaten Alor. Salah satu UMKM yang bergerak dalam pengelolaan hasil-hasil perkebunan adalah KUD Beringin di Apui Kecamatan Alor Selatan yang memproduksi kopi bubuk kemasan dengan merk Kopi Lonsilar dan UPH Perkebunan di Dinas Pertanian Perkebunan Kabupaten Alor yang memproduksi kopi bubuk kemasan dengan merk Kopi Cita Rasa Khas Alor (Demang, 2003).

Pengelolaan kedua kopi kemasan ini sudah berjalan beberapa tahun sebelumnya dalam bentuk kemasan plastik konvensional dengan memanfaatkan bahan baku kopi dari para petani kopi (kelompok petani kopi) yang tersebar di beberapa kecamatan di Kabupaten Alor (Arustiarso \& Widodo, 2015). Kecamatan Alor Selatan adalah salah satu wilayah yang memiliki desa dengan kelompok-kelompok petani yang mengolah tanaman kopi, diantaranya Desa Manmas yang terdapat 5 kelompok petani, mengolah \pm 250 ha kopi jenis robusta, masing-masing kelompok memiliki 25 anggota. Kelima kelompok sebagai petani kopi ini sekaligus sebagai pemasok bahan baku kopi (Kopi HS) ke koperasi/pasar di Kabupaten Alor. Adapun kelima kelompok tersebut adalah Kelompok Tani Webul, Kelompok Tani Mekar Jaya, Kelompok Tani Obat Mas, Kelompok Tani Kembang Baru dan Kelompok Tani Tunas Leibuk.

Pemasaran biji kopi yang telah bersih (kopi HS) dari kelompok-kelompok petani di Desa Manmas, masih dijual dengan tujuan yang bervariasi, bukan saja dijual ke koperasi, namun juga ke pedagang lain yang langsung datang ke Manmas melalui pasar Manmas, atau terkadang para petani menjual langsung ke pasar kabupaten yang berjarak $\pm 60 \mathrm{~km}$. Variasi tujuan pemasaran ini terjadi karena kesekapatan harga yang belum tercapai antara pembeli dan petani, karena ada yang mau membeli dengan Rp. 50.000 per $\mathrm{kg}$ namun ada hanya bisa menawarkan dengan harga Rp. 35.000 per kg. UMKM yang juga sering mengambil hasil kopi HS masyarakat kelompok petani Manmas adalah KUD Beringin yang berada di Desa Apui, yang berjarak $\pm 15 \mathrm{~km}$ dari Desa Manmas dan UPH Perkebunan di Kantor Dinas Perkebunan Kabupaten Alor yang berjarak \pm 60 km. Sebagai pihak-pihak yang membeli kopi HS dari kelompok tani, KUD Beringin dan UPH Perkebunan, memanfaatkan kopi HS bukan untuk dijual kembali, namun kopi HS tersebut 
diolah menjadi kopi bubuk dan dijual melalui koperasi dalam bentuk kemasan dengan merk Kopi Lonsilar dan Kopi Cita Rasa Khas Alor.

Pengembangan pengolahan Kopi Lonsilar dan Kopi Cita Rasa Khas Alor ini telah banyak dibantu oleh berbagai pihak, baik pemerintah daerah maupun beberapa lembaga lain. Salah satunya adalah DRPM Kemenristekdikti melalui Program Pengembangan Produk Unggulan Daerah yang dilakukan melalui Politeknik Negeri Kupang bersama LPPM Universitas Tribuana Kalabahi (Laumal, Wabang, Hattu, \& Plaimo, 2017). Bantuan dari DRPM telah direalisasikan berupa pengembangan fasilitas, pelatihan dan pendampingan dengan target kedua roduk kemasan tersebut dapat didistribusikan dna dipasarkan keluar dari Pulau Alor. Kopi Lonsilar yang sejak awal hanya dijual dalam kemasan plastik 50 gram, koni dijual dalam 3 ukuran kemasan yaitu 50 gram, 100 gram dan 250 gram. Sedangkan Kopi Cita Rasa Khas Alor dijual dalam kemasan 250 gram. Karena distribusi penjualan kedua kopi kemasan ini hanya tersebar di wilayah Apui dan Kota Kalabahi saja atau sebagai hanya dijadikan oleh-oleh oleh para pendatang yang suka menikmati minuman lokal, maka kolaborasi 2 perguruan tinggi melalui program DRPM berupaya bersama pemerintah daerah (dalam hal ini Dinas Perkebunan Kabupaten Alor) mengangkat produktifitas kopi olahan sehingga dapat didistribusikan hingga keluar daerah Kabupaten Alor secara berkelanjutan dan memberikan sumbangsih kepada peningkatan perekonomian masyarakat dan pendapatan daerah (Laumal, Wabang, Suharto, Lapinangga, \& Hutubessy, 2016). Pemerintah Kabupaten Alor melalui Dinas Pertanian dan Perkebunan sebagai pembina pengelolaan hasil-hasil perkebunan di wilayah ini telah banyak memiliki program bersama petani dan UMKM, baik pendampingan, pelatihan maupun bantuan lain yang berhubungan dengan aktifitas pengolahan hasil perkebunan (Atama, 2013; Prasetyo, Alaydrus, \& Dama, 2018) Namun berbagai faktor masih menjadi kendala terjadinya peningkatan pemasaran hasil olahan tenaman perkebunan; termasuk Kopi Lonsilar dan Kopi Cita Rasa Khas Alor, keluar dari Pulau Alor bahkan secara regional/nasional.

Dengan beberapa latar belakang di atas, diperlukan sebuah sinergitas antara pihakpihak yang memiliki kepentingan dalam pengelolaan Lonsilar dan Kopi Cita Rasa Khas Alor menuju pemasaran yang lebih luas, meliputi para kelompok petani kopi, UMKM/koperasi yang memproduksi kopi, pemerintah daerah dan target pembeli (pasar) agar memiliki komitmen yang sama untuk memajukan produk lokal menjadi produk yang dikenal di Alor dan di luar Alor atau dimana saja sekaligus memberikan keuntungan ekonomis bagi masyarakat dan daerah.

\section{METODE PELAKSANAAN}

Sinergitas pengembangan pemasaran produk kopi kemasan lokal di Kabupaten Alor ini melibatkan 4 pihak yang berkepentingan, yaitu Petani Kopi dari Desa Manmas Kecamatan Alor Selatan yang memiliki perkebunan kopi, UMKM yang memproduksi kopi kemasan Lonsilar dan Kopi Cita Rasa Khas Alor yaitu KUD Beringin dan UPH Perkebunan, Pemerintah Daerah melalui Dinas Pertanian Perkebunan Kabupaten Alor dan Pasar Modern yaitu PT Transmart Kupang. Sinergitas dilakukan dengan 2 tahapan, yaitu lokakarya bersama dan pameran kopi. 
Lokakarya dilaksanakan selama 2 hari memaparkan pandangan dan keinginan dari semua pihak meliputi keinginan harga, layanan, pendampingan, nomenklatur pengelolaan dan pendampingan terhadap hasil-hasil perkebunan, termasuk keinginan dan syarat dari pembeli/pasar meodern sebagai calon distributor sekaligus pembeli kedua produk lokal kemasan dari Alor tersebut. Pameran kopi dilaksanakan bersama dalam kegiatan festival pemerintah melalui penyediaan minuman kopi gratis pada saat kegiatan festival. Semua kegiatan dipusatkan di Kalabahi, ibukota Kabupaten Alor dan dibiayai oleh RPPM Kemristekdikti.

\section{HASIL DAN PEMBAHASAN}

Sebagai upaya membangun sinergitas antara pihak-pihak yang berkepentingan dalam pengelolaan produk perkebunan dalam bentuk kemasan dan dalam upaya mempertahankan keberlangsungan produksi, maka dilakukan sebuah lokakarya atau rembuk bersama antara kelompok petani kopi dari Alor Selatan, KUD beringin dan UPH Perkebunan, Dinas Pertanian Perkebunan Kabupaten Alor dan PT Transmart Kupang. Lokakarya ini dilaksanakan di AULA Kampus Universitas Tribuana Kalabahi dengan menghadirkan 3 pembicara dari pemerintah, PT Transmart Kupang dan Akademisi (Dosen).

Lokakarya ini mengambiil thema: " Sinergitas Pengelolaan Kopi Alor, Kopi Cita Rasa Khas Alor dan terdapat 5 kelompok tani yang dihadirkan dalam lokakarya ini, yaitu Kelompok Tani Webul, Kelompok Tani Mekar Jaya, Kelompok Tani Obat Mas, Kelompok Tani Kembang Baru dan Kelompok Tani Tunas Leibuk. Kelima kelompok tani ini memiliki lahan kopi masing-masing \pm 30 ha di wilayah Kecamatan Alor Selatan, tepatnya di Desa Manmas. Setiap tahun hasil panen kopi dari kelima kelompok tani ini dijual juga ke KUD Beringin dan KUD Perkebunan. Kehadiran kelompok petani dalam lokakarya menyatukan persepsi distribusi agar ketika produk kemasan asli Alor sudah masuk ke pasaran nasional, kelompok-kelompok ini harus tetap mendukung keberlanjutan supply bahan baku ke koperasi yang memproduksi kopi kemasan. KUD Beringin Apui dan UPH Pengolahan Kopi di Dinas Perkebunan, sebagai 2 mitra yang selama ini memproduksi dan menjual Kopi Lonsilar dan Kopi Cita Rasa Khas Alor dalam bentuk kemasan dan sebagai penerima program IbPUD. Pemerintah Daerah Kabupaten Alor melalui Dinas Pertanian dan Perkebunan Kabupaten Alor sebagai pembina pengelolaan tanaman perkebunan dna hasil-hasil perkebunan yang berada di Kabupaten Alor. Adapun peserta yang dihadirkan dalam lokakarya, adalah LPPM Universitas Tribuana Kalabahi sebagai perguruan tinggi di Alor dan mahasiswa-mahasiswi Program Studi Agribisnis dan Teknik Pengolahan Tanaman dari Universitas Tribuana Kalabahi.

Adapun materi yang diberikan dalam lokakarya tersebut, adalah: 1) Manager Senior PT Transmart Kupang dengan thema "Memperkenalkan produk-produk lokal Nusa Tenggara Timur melalui penyiapan media pemasaran bagi kopi kemasan lokal dari Kabupaten Alor", 2) Kepala Dinas Pertanian dan Perkebunan Kabupaten Alor dengan thema "Strategi Pengelolaan Tanaman Perkebunan di wilayah Kabupaten Alor dalam upaya peningkatan usaha kecil menengah masyarakat yang berdaya guna dan berdaya saing demi peningkatan taraf hidup masyarakat dan daerah", 3) Dosen Universitas Tribuana Kalabahi dengan thema "Strategi Pengelolaan Tri Dharma Perguruan Tinggi 
bidang Penelitian dan Pengabdian Masyarakat terhadap peluang pengelolaan tanaman pertanian dan perkebunan di Kabupaten Alor"

Upaya lain yang dilakukan dalam membangun sinergitas dan mendukung promosi produk kopi kemasan yang telah diproduksi, adalah terlibat dalam kegiatan-kegiatan pameran dilakukan oleh pemerintah daerah. Pameran merupakan suatu kegiatan terbuka yang menghadirkan banyak orang dari berbagai kalangan. Karena berbaai UKM/Koperasi memaerkan seluruh hasil olahan mereka (makanan dan hasil lokal daerah), maka KUD Beringin dan UPH Perkebunan juga memanfaatkan untuk memamerkan Kopi Lonsilar dan Kopi Cita Rasa Khas Alor. Meskipun kegiatan hanya berlangsung beberapa jam saja, namun banyak pengunjung yang telah menikmati kopi alor dari 2 mitra IbPUD.

Sasaran yang diharapkan dalam keikutsertaan dalam pameran produk olahan lokal Kabupaten Alor ini adalah lebih memperkenalkan Kopi Lonsilar dan Kopi Cita Rasa Khas Alor kepada masyarakat luas, sehingga ketika produk ini sudah beredar secara nasional melalui toko modern, masyarakat tidak terlalu kaget lagi dengan kehadirannya, karena mereka sudah pernah menikmati dan merasakan nikmat dan kualitasnya.

Berdasarkan dua kegiatan sebagai bentuk sinergitas antara berbagai pihak yang berkepentingan dalam pengelolaan kopi, akhirnya memberikan pengaruh peningkatan produksi dan penjualan pada kopi kemasan yang diproduksi oleh kedua koperasi. Secara keseluruhan, perkembangan produksi kopi kemasan dan penjualannya diberikan pada Gambar 1 dan Gambar 2 berikut.

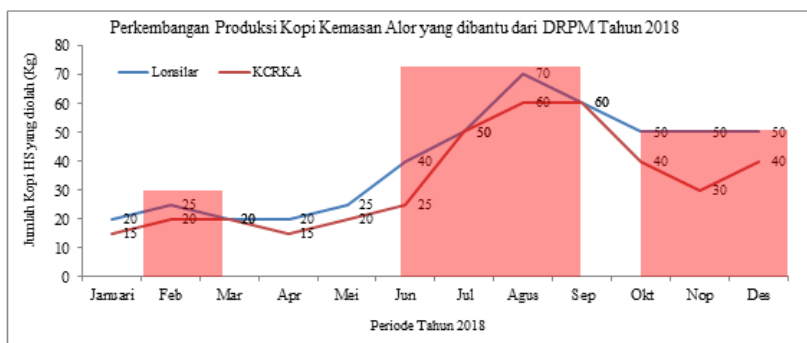

Gambar 1. Produksi Kopi Kemasan Alor 2018

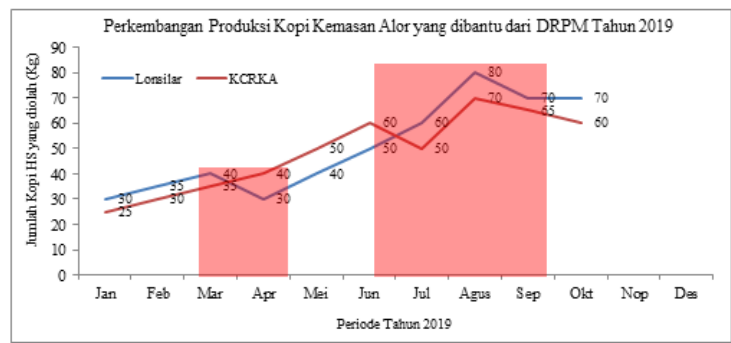

Gambar 2. Produksi Kopi Kemasan Alor 2019

Gambar 1 menampilkan perkembangan produksi kopi lokal Alor tahun 2018, yang diproduksi oleh KUD Beringin dan UPH Perkebunan yang pengelolaannya dibantu oleh Program Pengabdian DRPM. Sumbu x menampikan periode 1 tahun selama 2018 (Januari-Desember), sedangkan sumbu y menampilkan jumlah kopi yang diolah menjadi kopi bubuk (kg). Secara rinci, Gambar 1 menjelaskan bahwa produksi kopi Lonsilar yang diproduksi oleh KUD Beringin mengalami peningkatan produksi di 4 bulan pertama, sempat menurun di bulan kelima. Produksi kemudian mengalami peningkatan yang signifikan hingga tertinggi di bulan agustus. Produksi kembali menurun ke bulan nopember dan meningkat kembali di akhir tahun 2018. Sementara untuk produksi Kopi Cita Rasa Khas Alor (CRKA), tidak mengalami perningkatan di tiga bulan pertama, namun meningkat perlahan hingga tertinggi di bulan agustus. Produksi kenudian menurun tajam hingga bulan nopember dan meningkat kembali di akhir tahun 2018.

Gambar 2 menampilkan perkembangan produksi untuk tahun 2019 sampai Bulan Oktober 2019. Sumbu x menampikan periode 1 tahun selama 2019 (Januari-Desember), sedangkan sumbu y menampilkan jumlah kopi yang diolah menjadi kopi bubuk (kg). Secara rinci, 
Gambar 2 menjelaskan bahwa produksi kopi Lonsilar yang diproduksi oleh KUD Beringin mengalami peningkatan secara fluktiatif pada 4 bulan pertama kemudian meningkat secara signifikan hingga tertinggi di bulan agustus, namun produksinya kembali menurun di bulan Oktober. Sementara untuk produksi Kopi Cita Rasa Khas Alor (CRKA), mengalami perkembangan produksi yang hampir sama dengan Kopi Lonsilar, hanya peningkatannya tertinggi pada bulan September dan menurun kembali di Bulan Oktober 2019.

Dari gambaran perkembangan produksi Kopi Lonsilar dan Kopi Cita Rasa Khas Alor pada 2 tahun terakhir, terlihat bahwa peningkatan penjualan selalu terjadi pada bulan juli, agustus dan september ketika bertepatan dengan hari libur dan pameran-pameran. Selain itu tren meningkat juga terjadi pada setiap akhir tahun.

\section{KESIMPULAN}

Lokakarya merupakan salah satu upaya mempertemukan berbagai pihak yang berkepentingan dalam pengelolaan Kopi Alor yang berkelanjutan demi peningkatan pendapatan masyarakat dan daerah. Keterlibatan pameran kopi dalam kegiatan-kegiatan berskala lokal dan regional ikut mempromosikan kebreadaan kopi lokal Alor kepada masyarakat luas. Peningkatan produksi sebagai dampak dari pendampingan DRPM cukup baik pada 2 tahun terakhir. Tren peningkatan selalu terjadi pada masa liburan dimana banyak pendatang yang menjadikan kopi sebagai oleh-oleh dan masa pameran pembangunan yang selalu dilaksanakan oleh pemerintah daerah setiap tahun. Sinergitas memberi pengaruh kepada keberlanjutan produksi dan penjualan kopi kemasan dari Alor, dan memungkinkan untuk berkembang hingga skala nasional.

\section{UCAPAN TERIMA KASIH}

Terima kasih kepada DRPM Kemenristekdikti yang telah membiayai pelaksanaan program Pengabdian Masyarakat multi tahun dengan skema IbPUD untuk pengelolaan Kopi di Alor, Nusa Tenggara Timur. Program IbPUD ini berjalan selama 3 tahun dan selutuh pembiayaan bersumber kepada dana DIPA DRPM Kemenristekdikti.

\section{REFERENSI}

Arustiarso, \& Widodo, P. (2015). Pengembangan Mesain Sangrai Kopi berbahan Dasar Lokal di Kabupaten Alor NUsa Tenggara Timur. Prosiding Seminar Nasinal OPtimalisasi Potensi SUmber Daya Lokal Menghadapi MEA 2015.

Atama, S. J. (2013). Analisis Potensi Ekonomi Lokal untuk Pengembangan dan Penguatan Daya Saing Daerah di Kabupaten Alor Tahun 2009-2013. Jurnal Teknologi, 1(1), 69-73. https://doi.org/10.11113/jt.v56.60

Demang, F. (2003). Partner. 558-566. 
Gorangmau, N. K. (2016). Analisis Pemasaran Biji Jambu Mete Di Kabupaten Alor (Uniersitas Sebelas Maret). https://doi.org/10.1017/CBO9781107415324.004

Indonesia, R. (2004). UU RI Nomor 32 Tahun 2004. In undang-Undang Republik Indonesia Nomor 32. $\quad$ Retrieved from www.dpr.go.id/dokjdih/document/uu/33.pdf\%0D

Laumal, F. E., Wabang, J. A., Hattu, E. P., \& Plaimo, P. E. (2017). Peningkatan Produksi Kopi Lonsilar Pada KUD Beringin. In F. E. Laumal, J. A. Wabang, E. P. Hattu, \& P. E. Plaimo (Eds.), Seminar Nasional Vokasi dan Teknologi (Semnasvoktek) 2017 (pp. 366-373). https://doi.org/10.17605/OSF.IO/YFXJ8

Laumal, F. E., Wabang, J. A., Suharto, R. S. B., Lapinangga, N., \& Hutubessy, J. I. B. (2016). Peran Perguruan Tinggi dalam Pengelolaan Perkebunan Kopi. 5-8.

Ma'rif, S. (2016). Strategi Pengembangan Perdesaan Kawasan Perbatasan, Studi Kasus: Kawasan Perbatasan Republik Indonesia-Ambenu Republik Demokratik Timor Leste. Tataloka, 14(1), 75-89. https://doi.org/10.14710/tataloka.14.1.75-89

Prasetyo, R. H. D., Alaydrus, A., \& Dama, M. (2018). Peran upt penyuluhan dan pengembgan perkebunan rakyat dalam pembinaan kelompok tani di kecamatan muara jawa kabupaten kutai kartanegara. 6(3), 1121-1130.

Rema, I. N., \& Prihatmoko, H. (2016). Potensi Arkeologi di Pulau Alor. Kalpataru, 25(2), 103. https://doi.org/10.24832/kpt.v25i2.109 